\section{Summary}

Fourteen accidents involving agricultural tractors are described.

If a driver is injured when a tractor overturns the chances are shown to be about one in four that he will be killed.

Tractor accidents are shown to have a much higher mortality and serious-injury rate than road-traffic accidents.

Tractor accidents produce injuries of the crush type, and the trunk is more likely to be injured than the head or extremities.

The type of man most likely to be involved in a tractor accident is one who is married, who is an experienced driver, and who is over 30 years old.

Tractors should be provided with safety frames that are strong enough to protect the drivers from being crushed should the vehicles overturn.
I wish to thank H.M. Coroner and the Chief Constable of MidWales for the information obtained from the coroner's records and from the police reports of road-traffic accidents. I am grateful to my partners (Drs. T. Brittain and H. G. Davies), and also to Dr. Lee Shimmin, for allowing me to quote cases for which they were primarily responsible. My thanks are also due to the matron and staff of Llanidloes Hospital, where many of the patients were treated, and to $\mathrm{Mr}$. H. Johnston Jones for translating the French papers. The help of Sgt. V. Davies and the local police constables is gratefully acknowledged.

\section{REFERENCES}

Coe, M. (1959). F. Kans. med. Soc., 60, 70. Dervillée, E. (1963). Concours méd., 85, 1037.

(1964a). Ibid., 86, 511.

(1964b). Gaz. méd. Fr., 71, 691

McLaughlin, C. W., and Coe, J. D. (1960). Postgrad. Med., 27, 165.

Miedviet (1961). Quoted by Dervillée (1964a).

Ministry of Agriculture, Fisheries, and Food (1964). Report on Safety, Health, Welfare, and Wages in Agriculture, 1 October 1962 to 30 Health, Welfare, and Wages in Agricul Road Accident Statistics (1963). Published by Ro.S.P.A., London. Snyder, H. E. (1955). Postgrad Med., 18, 332.

\title{
Organo-chlorine Pesticide Residues in Human Fat and Human Milk
}

\author{
H. EGAN, B.SC., PH.D., F.R.I.C. ; R. GOULDING, M.D., B.SC. ; \\ J. ROBURN, B.SC. ; J. O'G. TATTON, M.SC., F.R.I.C.
}

Brit. med. F., 1965, 2, 66-69

Over recent years considerable interest has been aroused by reports on studies carried out in various countries showing the presence of dieldrin and D.D.T. residues in human body fat. An official committee, after studying the available evidence, stated (Report, 1964) that, whereas there is no evidence to date that levels of these pesticides hitherto reported in human tissues do any harm or that they present any serious immediate hazard to human beings, the fact that traces of these compounds are found in so many situations is a matter of some concern. The only other surveys of human fat in the U.K. have been confined to south-east England (Hunter et al., 1963 ; Robinson et al., 1965), but in the present study sampling has been extended to other centres in England and Wales, and samples of human breast milk have also been examined. This study was initiated by the Advisory Committee on Pesticides and Other Toxic Chemicals, and was carried out jointly by the Ministry of Health and the Laboratory of the Government Chemist, Ministry of Technology, together with the assistance of a number of forensic pathologists and directors of human breast milk banks.

\section{Experimental Methods and Materials}

Between April 1963 and March 196465 samples of human perirenal fat, each of not less than $5 \mathrm{~g}$., were collected by pathologists in the course of routine post-mortem examinations, and two more were taken with the agreement of patients by subcutaneous biopsy. The specimens were placed in prepared glass containers, sent to the Laboratory of the Government Chemist, and stored at approximately $-20^{\circ}$ C. prior to analysis. Over the same period 19 samples of human breast milk were collected in quantities of about $100 \mathrm{ml}$. when surpluses were available at milk banks. These also were sent to the Laboratory of the Government Chemist in prepared glass containers and stored at about $3^{\circ} \mathrm{C}$. prior to analysis.
Samples of fat were first freed from any adhering non-fatty material, washed with distilled water, and dried with cellulose tissue. Residues of organochlorine pesticides were estimated in fat and milk by procedures previously described (de Faubert Maunder et al., 1964a, 1964b), using two gas chromatographic columns of differing polarities for each sample. When the levels of $p p^{\prime}$-D.D.E. and $p p^{\prime}$-D.D.T. were sufficiently high, further confirmation of the results was obtained by paper chromatography (Evans, 1962).

\section{Human Fat}

Results

The results for D.D.E., D.D.T., total D.D.T. equivalent, total B.H.C. isomers, and dieldrin (H.E.O.D.) in human fat, expressed in parts per million, are given in Table I. This table omits results for one subject in whose fat exceptionally high $p p^{\prime}$-D.D.E. and $p p^{\prime}-$ D.D.T. levels, 26 and 25 parts per million respectively, were found and who on further inquiry proved to have been a recent immigrant from Pakistan. The total D.D.T. equivalent has been calculated by addition of the $p p^{\prime}$-D.D.T. equivalent of the $p p^{\prime}-$ D.D.E. found to the level of $p p^{\prime}$-D.D.T. found as such. Since $p p^{\prime}$-D.D.E. is relatively nontoxic, the total $p p^{\prime}-$ D.D.T. equivalent figure may be regarded as the maximum indication of any hazard from this pesticide. Normally the alpha, beta, and gamma isomers of B.H.C. were found in all samples, but beta-B.H.C. usually predominated to the extent of about $90 \%$ of the total B.H.C. Beta-B.H.C. is reported to have a lower acute toxicity but a higher chronic toxicity than the other isomers (Lehman, 1951 ; Martin, 1961). A trace of heptachlor epoxide, in no case exceeding 0.1 part per million, was also detected in most samples.

These results have been considered statistically. As noted in the earlier survey, the distribution of $p p^{\prime}-D . D . T$. and dieldrin levels is skew; for this reason individual results have been 
transformed in the manner described previously (Hunter et al., 1963) and are given in Table II. It will be seen that while the geometric mean level observed for dieldrin is identical with that found in the earlier work, the present geometric mean for total D.D.T.-equivalent is somewhat higher than that reported for South-east England alone. Examining the subjects from the south and the north of England separately (Table III), the respective geometric means for total D.D.T.-equivalent are found to be 2.5 and 3.5 p.p.m. In view of the comparatively small number of subjects examined in this way, however, there is little justification for supposing that the difference of 1 p.p.m. does not arise by chance or that there is any significant difference between the means in the two surveys. To distinguish between two distributions showing a similar variation and whose means differ by 1 p.p.m. a much larger sampling programme would

\begin{tabular}{|c|c|c|c|c|c|c|c|}
\hline Sex & Age & $\begin{array}{c}p p^{\prime}- \\
\text { D.D.T. }\end{array}$ & $\begin{array}{c}p p^{\prime} \cdot \\
\text { D.D.E. }\end{array}$ & $\begin{array}{l}\text { Total } \\
\text { D.D.T. } \\
\text { Equiva- } \\
\text { lent }\end{array}$ & $\begin{array}{l}\text { Total } \\
\text { B.H.C. }\end{array}$ & $\begin{array}{l}\text { Diel- } \\
\text { drin }\end{array}$ & Origin \\
\hline 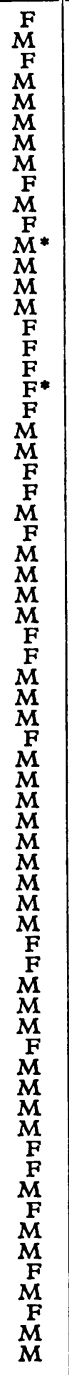 & \begin{tabular}{c|}
$1 \frac{1}{2}$ \\
$1 \frac{1}{2}$ \\
12 \\
17 \\
18 \\
19 \\
20 \\
22 \\
23 \\
23 \\
23 \\
24 \\
27 \\
30 \\
31 \\
31 \\
33 \\
34 \\
35 \\
36 \\
39 \\
41 \\
42 \\
43 \\
45 \\
46 \\
50 \\
51 \\
53 \\
55 \\
56 \\
57 \\
57 \\
59 \\
60 \\
61 \\
61 \\
61 \\
61 \\
61 \\
62 \\
62 \\
63 \\
64 \\
65 \\
66 \\
66 \\
67 \\
68 \\
68 \\
69 \\
69 \\
72 \\
76 \\
76 \\
76 \\
78 \\
78 \\
80 \\
80 \\
80 \\
80 \\
82 \\
84 \\
88
\end{tabular} & 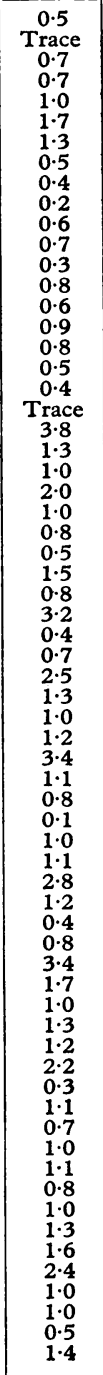 & $\begin{array}{l}0.6 \\
0.3 \\
0.5 \\
1.5 \\
0.6 \\
4.0 \\
3.1 \\
1.5 \\
2.1 \\
0.8 \\
0.5 \\
0.8 \\
0.3 \\
1.4 \\
1.4 \\
2.4 \\
1.7 \\
1.0 \\
0.9 \\
0.1 \\
1.9 \\
2.9 \\
2.0 \\
2.2 \\
1.6 \\
1.4 \\
1.4 \\
3.2 \\
2.4 \\
4.8 \\
0.5 \\
1.0 \\
4.2 \\
1.8 \\
2.2 \\
1.8 \\
3.9 \\
1.8 \\
1.9 \\
2.8 \\
4.0 \\
3.8 \\
4.3 \\
2.2 \\
0.5 \\
1.7 \\
4.1 \\
2.7 \\
0.9 \\
1.8 \\
1.8 \\
3.4 \\
0.3 \\
2.2 \\
1.3 \\
2.3 \\
2.4 \\
2.3 \\
0.8 \\
2.7 \\
2.1 \\
1.9 \\
4.0 \\
1.1 \\
1.0 \\
3.3\end{array}$ & 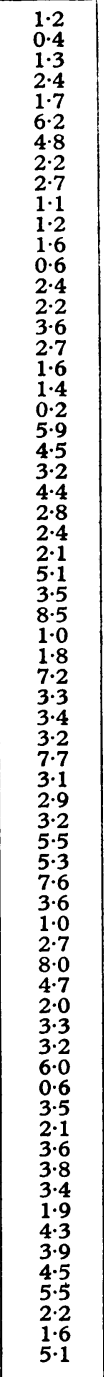 & 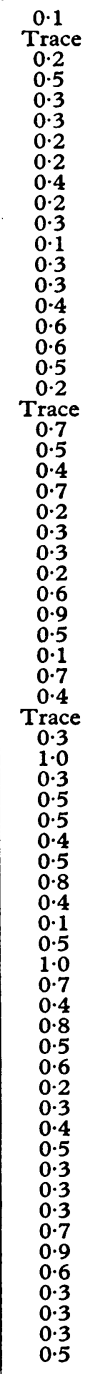 & 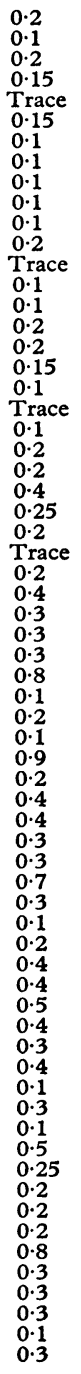 & $\begin{array}{l}\text { Z } \\
\text { Cardiff } \\
\text { Liverpool } \\
\text { - } \\
\text { Newcastle } \\
\text { Carlisle } \\
\text { London } \\
\text { London } \\
\text { Carlisle } \\
\text { Carlisle } \\
\text { London } \\
\text { Carlisle } \\
\text { Newcastle } \\
\text { London } \\
\text { Carlisle } \\
\text { London } \\
\text { Carlisle } \\
\text { London } \\
\text { Carlisle } \\
\text { Newcastle } \\
\text { London } \\
\text { - } \\
\text { Bolton } \\
\text { Carlisle } \\
\text { London } \\
\text { London } \\
\text { Cardiff } \\
\text { Cardiff } \\
\text { Leeds } \\
\text { London } \\
\text { Newcastle } \\
\text { London } \\
\text { London } \\
\text { London } \\
\text { Cardiff } \\
\text { London } \\
\text { London } \\
\text { Leeds } \\
\text { Leeds } \\
\text { London } \\
\text { Cardiff } \\
\text { Bolton } \\
\text { London } \\
\text { London } \\
\text { London } \\
\text { Cardiff } \\
\text { Portsmouth } \\
\text { Carlisle } \\
\text { Cardiff } \\
\text { Bolton } \\
\text { Cardiff } \\
\text { London } \\
\text { Newcastle } \\
\text { Portsmouth } \\
\text { London } \\
\text { Cardiff } \\
\text { Carlifle } \\
\text { Carlisle } \\
\text { Bournemouth } \\
\text { Bolton } \\
\text { Cardiff } \\
\end{array}$ \\
\hline
\end{tabular}

* Biopsy samples.

TABLE II.-Mean Pesticide-residue Levels in FIuman Fat (All Levels are Expressed in Parts Per Million)

\begin{tabular}{|c|c|c|c|}
\hline & Total B.H.C. & Dieldrin & $\begin{array}{c}\text { Total D.D.T.- } \\
\text { equivalent }\end{array}$ \\
\hline 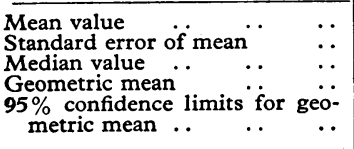 & $\begin{array}{c}0.42 \\
0.03 \\
0.39 \\
0.34 \\
0.29-0.41\end{array}$ & $\begin{array}{c}0 \cdot 26 \\
0 \cdot 02 \\
0 \cdot 18 \\
0 \cdot 21 \\
0 \cdot 17-0 \cdot 24\end{array}$ & $\begin{array}{l}3 \cdot 3 \\
0.24 \\
3 \cdot 2 \\
2 \cdot 7 \\
2 \cdot 3-3 \cdot 2\end{array}$ \\
\hline
\end{tabular}

be required. Similarly, when the subjects are distributed between two residue ranges the difference between the distributions for the two areas is such that it could easily arise by chance. The mean value of 0.39 p.p.m. for total B.H.C. is about twice the value found for American subjects by Dale and Quinby (1963). Hoffman et al. (1964), in a more recent American survey, report an average level of 0.56 p.p.m. for 282 samples or 0.51 p.p.m. for 279 samples when three very high values are rejected.

TABLE III.-D.D.T.-equivalent Residues (p.p.m.) in Human Fat and Geographical Location

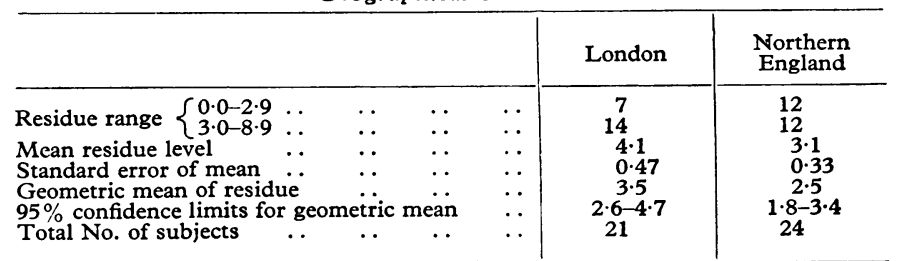

The distribution of the 66 subjects by both age and residue level is shown in Table IV. There is a somewhat higher proportion of the under-30 age group, with a correspondingly lower proportion of the over-70 age group in the present survey as compared with the earlier one. The proportion of male to female does not differ significantly between the two surveys.

TABle IV.-Distribution of Pesticides in Human Fat by Age and Residue

\begin{tabular}{|c|c|c|c|c|c|c|}
\hline \multicolumn{7}{|c|}{$\begin{array}{l}\text { Level } \\
\end{array}$} \\
\hline \multirow{2}{*}{\multicolumn{3}{|c|}{ Pesticide }} & \multirow{2}{*}{$\underset{\text { (p.p.m.) }}{\text { Residue Range }}$} & \multicolumn{3}{|c|}{ Age Group in Years } \\
\hline & & & & $1-39$ & $40-63$ & 64-88 \\
\hline Total B.H.C. & & .. & $\left\{\begin{array}{l}0 \cdot 0-0 \cdot 2 \\
0 \cdot 3-0 \cdot 4 \\
0 \cdot 5-1 \cdot 0\end{array}\right.$ & $\begin{array}{l}9 \\
7 \\
6\end{array}$ & $\begin{array}{r}4 \\
8 \\
10\end{array}$ & $\begin{array}{r}2 \\
9 \\
11\end{array}$ \\
\hline Dieldrin & & . & $\left\{\begin{array}{l}0.0-0.1 \\
0.2-0.9 \\
0.3-0.9\end{array}\right.$ & $\begin{array}{r}13 \\
9 \\
0\end{array}$ & $\begin{array}{r}3 \\
5 \\
14\end{array}$ & $\begin{array}{r}4 \\
4 \\
14\end{array}$ \\
\hline Total D.D.T. & valent & .. & $\left\{\begin{array}{l}0 \cdot 0-1 \cdot 9 \\
2 \cdot 0-3 \cdot 9 \\
4 \cdot 0-8 \cdot 9\end{array}\right.$ & $\begin{array}{r}11 \\
7 \\
4\end{array}$ & $\begin{array}{r}2 \\
12 \\
8\end{array}$ & $\begin{array}{r}4 \\
11 \\
7\end{array}$ \\
\hline
\end{tabular}

In the present survey the proportion of subjects in the lowest residue range for each pesticide is greatest for the 1-39 year age group, the distribution of the levels among the three residue ranges being much the same for the two upper age groups. Thus the distribution of the pesticide levels among the subjects in the 40-63 year age group does not differ significantly from that for the 64-88 year age group, while both of these distributions differ significantly from that for the 1-39 year age group.

The evidence in the three pesticides sections of the table cannot be regarded as independent, since for each the same 66 subjects are examined. Examination of the individual results for total D.D.T.-equivalent and dieldrin show that there is a significant but not very precise correlation between the two, as shown in Table V.

TABLE V.-Correlation Between Dieldrin and Total D.D.T.-equivalent Levels in Human Fat

\begin{tabular}{|c|c|c|c|c|}
\hline Total & D.T. (p.p.m.): & $0 \cdot 0-2 \cdot 9$ & $3 \cdot 0-5 \cdot 9$ & $6 \cdot 0-8.9$ \\
\hline $\begin{array}{r}\text { Dieldrin : } \\
0 \cdot 0-0 \cdot 2 \\
0 \cdot 3-0.6 \\
0.7-0.9\end{array}$ & $\begin{array}{ll}. & . \\
\because & \end{array}$ & $\begin{array}{r}25 \\
6 \\
0\end{array}$ & $\begin{array}{r}12 \\
15 \\
1\end{array}$ & $\begin{array}{l}1 \\
3 \\
3\end{array}$ \\
\hline
\end{tabular}

\section{Human Milk}

Table VI gives the results for $p p^{\prime}$-D.D.T., $p p^{\prime}$-D.D.E., total D.D.T.-equivalent, total B.H.C. isomers, and dieldrin in human milk, expressed in parts per million. As with human fat, nearly all the B.H.C. was present as the beta isomer, with only small amounts of the alpha and gamma isomers. In addition, traces of hepatachlor epoxide and of $p p^{\prime}-$ T.D.E. appeared to be present 
in all the samples, but in no case did these exceed 0.002 and 0.010 p.p.m. respectively. These results also show a skew distribution, but because of the small number of samples involved no further statistical treatment has been given to them.

TABle VI.-Pesticide Residues (p.p.m.) in Human Milk

\begin{tabular}{c|c|c|c|c|l}
\hline$p p^{\prime}$-D.D.T. & $p p^{\prime}$-D.D.E. & $\begin{array}{c}\text { Total D.D.T. } \\
\text { equivalent }\end{array}$ & $\begin{array}{c}\text { Total } \\
\text { B.H.C. }\end{array}$ & Dieldrin & Origin \\
\hline 0.030 & 0.040 & 0.075 & 0.009 & 0.002 & Cardiff \\
0.024 & 0.050 & 0.080 & 0.013 & 0.007 & Leicester \\
0.020 & 0.060 & 0.085 & 0.010 & 0.008 & Leicester \\
0.025 & 0.065 & 0.095 & 0.015 & 0.006 & Cardiff \\
0.040 & 0.055 & 0.100 & 0.012 & 0.004 & C. \\
0.050 & 0.060 & 0.115 & 0.007 & 0.004 & Cardiff \\
0.050 & 0.060 & 0.115 & 0.011 & 0.006 & Cardiff \\
0.045 & 0.065 & 0.115 & 0.017 & 0.008 & Leicester \\
0.045 & 0.075 & 0.130 & 0.010 & 0.002 & Leicester \\
0.050 & 0.070 & 0.130 & 0.011 & 0.007 & Cardiff \\
0.050 & 0.070 & 0.130 & 0.013 & 0.008 & Cardiff \\
0.035 & 0.085 & 0.130 & 0.010 & 0.011 & Cardiff \\
0.050 & 0.080 & 0.140 & 0.014 & 0.006 & London \\
0.055 & 0.085 & 0.150 & 0.013 & 0.004 & London \\
0.075 & 0.070 & 0.155 & 0.033 & 0.006 & Cardiff \\
0.040 & 0.100 & 0.150 & 0.013 & 0.005 & London \\
0.050 & 0.100 & 0.160 & 0.009 & 0.013 & Cardiff \\
0.065 & 0.090 & 0.165 & 0.015 & 0.001 & London \\
0.050 & 0.110 & 0.170 & 0.008 & 0.009 & Leicester \\
\hline
\end{tabular}

\section{Discussion}

The gas chromatographic techniques used in this study afford a high degree of specificity and sensitivity. Older colorimetric methods were usually based on nitration procedures, which are less sensitive. Being subject to interference from other isomers of D.D.T. and their breakdown products, they are also less specific, and can for this reason give misleadingly high results. These discrepancies have been discussed by Dale and Quinby (1963), who carried out paired analyses for $p p^{\prime}-$ D.D.T. in human fat by the two methods. Gas chromatography, however, can distinguish between the isomers and other interfering compounds, the amounts of which can be separately calculated.

As already noted, the dieldrin and D.D.T. findings in the two British surveys, both based on gas chromatographic measurement, are in reasonably close agreement. On comparison with D.D.T. results obtained overseas (Table VII), the immediate impression is that the residue levels prevailing in the fat of American subjects are appreciably higher than those present in Britain. Caution is, however, necessary owing to a predominance of colorimetric measurements in the American

TABLE VII.-Comparison of D.D.T./D.D.E. Levels Found in Human

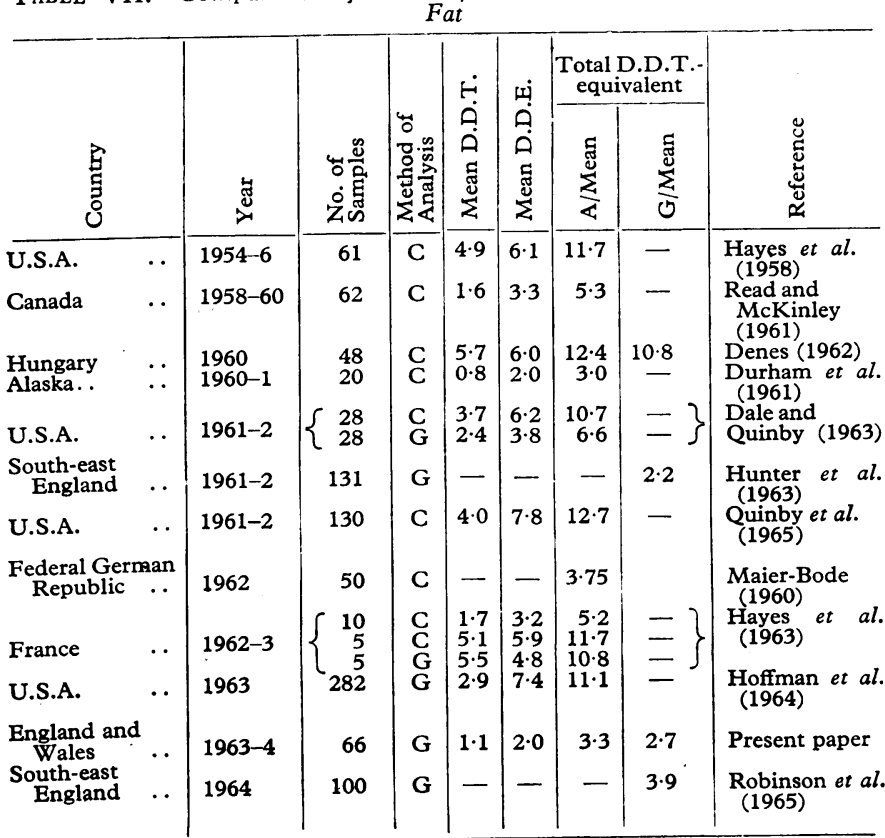

A/Mean = Arithmetric mean. G/Mean = Geometric mean.

$\mathrm{C}=$ Colorimetry. $\mathrm{G}=\mathrm{Gas}$ chromatography. studies. For dieldrin less extensive surveys have been made, but Table VIII suggests that the residues persisting in human fat are of the same order in both Britain and the United States.

TABLE VIII.-Comparison of Dieldrin Levels Found in Human Fat (All

\begin{tabular}{|c|c|c|c|c|c|}
\hline \multirow{2}{*}{ Country } & \multirow{2}{*}{ Date } & \multirow{2}{*}{$\begin{array}{l}\text { No. of } \\
\text { Samples }\end{array}$} & \multicolumn{2}{|c|}{ Dieldrin residue } & \multirow{2}{*}{ Reference } \\
\hline & & & A/Mean & G/Mean & \\
\hline U.S.A. $\quad$. & $1961-2$ & 28 & - & $0 \cdot 15$ & $\begin{array}{l}\text { Dale and Quinby } \\
\text { (1963) }\end{array}$ \\
\hline $\begin{array}{l}\text { South-east } \\
\text { England } \\
\text { England and }\end{array}$ & $1961-2$ & 131 & - & 0.21 & Hunter et al. (1963) \\
\hline $\begin{array}{l}\text { Enggandes and } \\
\text { Wales. } \\
\text { U.S.A. }\end{array}$ & $\begin{array}{l}1963-4 \\
1963\end{array}$ & $\begin{array}{l}66 \\
64\end{array}$ & $\begin{array}{l}0.26 \\
0.11\end{array}$ & $\underline{0.21}$ & $\begin{array}{l}\text { Present paper } \\
\text { Hoffman et al. (1964) }\end{array}$ \\
\hline $\begin{array}{l}\text { South-east } \\
\text { England }\end{array}$ & 1964 & 100 & - & $0 \cdot 21$ & Robinson et al. (1965) \\
\hline
\end{tabular}

Mention deserves to be made of the source of the fat samples in the present investigation. With two exceptions the subjects had come to post-mortem examination on the instructions of a coroner. There were very few examples among them of chronic wasting disease and depleted fat reserves. There is good reason to believe that what was found in these cases would reliably reflect the levels prevailing in life. So far as they go, the results of the two biopsy samples confirm this.

All the human milk samples appear to contain traces of D.D.T., dieldrin, and B.H.C. The levels of all three in milk are some thirty times less than the corresponding levels in human fat, suggesting a distribution equilibrium in the fat phase of the body. Breast-fed babies may thus start their extrauterine existence in this country on a diet containing traces of organochlorine compounds. This is true also for infants fed on cows' milk, though the levels found in a preliminary survey of cows' milk in Britain (Report, 1964) are lower than for human milk, as shown in Table IX where the two are compared. The results for cows' milk, derived from concordant observations on the two gas chromatographic columns, are below the levels at which other techniques are available for residue identity confirmation. It would be interesting to determine whether the human foetus contains any organo-chlorine residues derived transplacentally from the maternal fat.

TABLE IX.-Comparison of Average Pesticide Residue Levels in Cows' Milk and Human Milk (p.p.m.)

\begin{tabular}{|c|c|c|c|c|c|c|}
\hline & $\begin{array}{l}\text { No. of } \\
\text { Samples }\end{array}$ & $\begin{array}{c}p p^{\prime}- \\
\text { D.D.T. }\end{array}$ & $\begin{array}{c}p p^{\prime}- \\
\text { D.D.E. }\end{array}$ & $\begin{array}{c}\text { Total } \\
\text { D.D.T.- } \\
\text { equiva- } \\
\text { lent }\end{array}$ & $\begin{array}{c}\text { Total } \\
\text { B.H.C. }\end{array}$ & Dieldrin \\
\hline $\begin{array}{ll}\text { Cows' milk } & \ldots \\
\text { Human milk } & \ldots\end{array}$ & $\begin{array}{l}60 \\
19\end{array}$ & $\begin{array}{l}0.002 \\
0.045\end{array}$ & $\begin{array}{l}0.002 \\
0.073\end{array}$ & $\begin{array}{l}0.004 \\
0.128\end{array}$ & $\begin{array}{l}0.003 \\
0.013\end{array}$ & $\begin{array}{l}0.003 \\
0.006\end{array}$ \\
\hline
\end{tabular}

None of the subjects in the present survey had succumbed to chronic organo-chlorine poisoning. From their histories, none of them had apparently suffered at all from the small residues which they had carried around. Nor does it seem that American subjects with appreciably higher residue levels in their bodies are any the worse for this. The question arises: What is the source of the pesticide residues found in human tissues in this and the other studies mentioned? Very few individuals are subject to occupational exposure. There is limited evidence of dietary contributions in Britain (Report, 1964) and the U.S. (Hayes et al., 1958). Hoffman concluded that there had been no progression of storage of D.D.T. in the general population of the United States in over a decade. What clearly will be of interest will be to continue the present survey for several years to see whether any trend becomes apparent.

\section{Summary}

Using gas chromatographic techniques, 65 samples of human perirenal fat collected post mortem, two more taken from patients 
by subcutaneous biopsy, and 19 samples of human breast milk were analysed quantitatively for D.D.E., D.D.T., total B.H.C. isomers, and dieldrin (H.E.O.D.). The material studied was derived from sources throughout England and Wales. Apart from one anomalous finding from a recent immigrant the levels in the fat ranged from 0.2 to 8.5 p.p.m. for total D.D.T.equivalent (mean 3.3), from a trace to 1.0 p.p.m. for total B.H.C. (mean 0.42), and from a trace to 0.9 p.p.m. for dieldrin (mean 0.26). In human breast milk the corresponding figures were 0.075 to 0.170 for total D.D.T.-equivalent, 0.009 to 0.033 for total B.H.C., and 0.002 to 0.013 for dieldrin.

In the provision of samples for this study we have enjoyed considerable help and co-operation from the directors of four human breast milk banks and from numerous pathologists throughout the country-so many, in fact, that it is hoped that they will forgo being named individually. To all of them our gratitude is expressed collectively. Thanks are also due to Dr. J. M. Barnes and Mr. O. F. Newman for the benefit of discussions with them at all stages of this work.
REFERENCES

Dale, W. E., and Quinby, G. E. (1963). Science, 142, 593.

de Faubert Maunder, M. J., Egan, H., Godly, E. W., Hammond, E. W., Roburn, J., and Thomson, J. (1964a). Analyst, 89, 168.

and Roburn, J. (1964b). Ibid., 89, 157.

Denes, A. (1962). Nahrung, 6, 48; and private communication.

Durham, W. F., Armstrong, J. F., Upholt, W. M., and Heller, C. (1961). Science, 134, 1880.

Evans, W. H. (1962). Analyst, 87, 569.

Hayes, W. J., Dale, W. E., and Le Breton, R. (1963). Nature (Lond.), 199,1189

199, 1189. G. E., Walker, K. C., Elliott, J. W., and Upholt, W. M. Quinby, G. E., Walker, K. C., Elliott
(1958). Arch. industr. Hlth, 18, 398.

Hoffman, W. S., Fishbein, W. I., and Andelman, M. B. (1964). F. Amer. med. Ass., 188, 819; Arch. environm. Health, 9, 387.

Hunter, C. G., Robinson, J., and Richardson, A. (1963). Brit. med. F., 1,221 .

Lehman, A. J. (1951). Quart. Bull. Ass. Fd Drug Off. U.S., 15, 122.

Maier-Bode, H. (1960). Med. exp. (Basel), 1, 146.

Martin, H. (1961). Guide to Chemicals Used in Crop Protection, 4th ed., p. 18. Canada Department of Agriculture.

Quinby, G. E., Hayes, W. J., Armstrong, J. F., and Durham, W. F. (1965). ₹. Amer. med. Ass., 191, 175.

Read, S. T., and McKinley, W. P. (1961). Arch. environm. Hlth, 3, 209.

Read, S. T., and McKinley, W. P. (1961). Arch. environm. Hlth, 3, 209. culture and Food Storage (1964). Review of Organo-chlorine Pesti-
contist cides. H.M.S.O., London.

Robinson, J., Richardson, A., Hunter, C. G., Crabtree, N., and Rees, H. J. (1965). Brit. F. industr. Med. In press.

\title{
Association of Oligomenorrhoea, Hirsuties, and Infertility
}

\author{
DAVID FERRIMAN,* D.M., F.R.C.P. ; ANTHONY W. PURDIE, $†$ M.B., CH.B., M.R.C.P.GLASG., F.R.C.S.GLASG., F.R.C.O.G.
}

Brit. med. F., 1965, 2, 69-72

A group of patients present with varying combinations of oligomenorrhoea, hirsuties, and infertility. They pose a number of aetiological and therapeutic problems. The following report concerns findings in a series observed at the North Middlesex Hospital in recent years.

\section{Material and Methods}

Altogether some 183 patients have been studied. Most of them attended at one gynaecological and one endocrine clinic complaining of oligomenorrhoea or hirsuties, or infertility found to be associated with one or other of these conditions. Minimal criteria demanded for a diagnosis of oligomenorrhoea were menstrual cycles exceeding 28 days by several days, occurring for a minimal period of one year ; in most instances, however, the cycles were much longer, ranging from five weeks to amenorrhoea for months or years, and the condition had been present for years or may even have dated from the menarche.

An attempt, not always successful, was made to complete a routine series of investigations in each patient.

1. A "hormonal" hair score was obtained according to the method of Ferriman and Gallwey (1961).

2. Basal temperature charts were kept for a minimum period of six months or three complete cycles-usually much longer, except in patients with prolonged periods of amenorrhoea.

3. Gynaecography was carried out after trans-abdominal induction of pneumoperitoneum. Some $900 \mathrm{ml}$. of air was introduced, and radiographs were taken with the patient lying prone and tilted head-downwards to an angle of 30 degrees with the horizontal, the $x$-ray tube being positioned $3 \mathrm{ft}$. $(91 \mathrm{~cm}$.) vertically above the perineum.

4. Twenty-four-hour excretions of 17-ketosteroids were estimated by the Medical Research Council (1951) method, and of pregnanetriol by James's (1961) method.

\section{* Physician, Endocrine Centre, North Middlesex Hospital, London.} + Senior Obstetrician and Gynaecologist, North Middlesex Hospital, London.
5, 6, and 7. Endometrial curettage and culture for Mycobacterium tuberculosis, hysterosalpingography, and analysis of the husband's semen were carried out in patients complaining of infertility.

Cortisone $37.5 \mathrm{mg}$. daily was employed in a series of patients for the relief of infertility, and in others for the correction of oligomenorrhoea and anovulatory cycles. Wedge-resection was employed for the relief of infertility in some patients with enlarged polycystic ovaries.

The findings are presented under two headings-those bearing on the question of aetiology and those relating to the effects of treatment.

\section{Aetiology}

Some consideration must first be given to methods of analysis of the data if findings are to be intelligible.

\section{Methods of Analysis}

Analysis of the data we obtained would have been helped by a knowledge of the ranges of normality for the various parameters involved and by the existence of methods for distinguishing between physiological and pathological departures from average figures. Unfortunately, information on these matters is somewhat limited.

The length of the menstrual cycle appears to be a graded characteristic. Haman (1942) and Marshall (1963) have reported on series of apparently normal regularly menstruating women: cycles of up to eight weeks were recorded, but any above six weeks seem to be somewhat unusual. Body hair is another graded characteristic. Ferriman and Gallwey (1961) describe a simple method of assessment for clinical purposes ; in a control series of apparently normal women scores of from 0 to 4 were found in $89 \%$ and from 5 to 9 in $10 \%$, but scores of 10 and upwards were found in only $1 \%$. Anovulatory 